The Orbit of $\sigma$ Corona Borealis.--As the orbits calculated from the observations of $\sigma$ Coronæ Borealis show great divergence, ranging from 200 to 800 years, Prof. Doberck has investigated this subject, and now publishes the results in No. $405 \mathrm{I}$ of the Astronomische Nachrichten. The set of elements which he gives depends upon Herschel's measures of the angle, and shows the period to be about 1679 years, and the motion to be direct.

Prof. Doberck states that the hypothetical parallax of this system is $0^{\prime \prime} \cdot 064$, but the actual parallax is probably smaller, and that the mass of the srstem is probably greater than that of the sun.

Radial Velocities of Certaix Variable Stars.-The results obtained by Prof. Frost from a series of spectrographic observations of certain variable stars (chiefly of the Algol type) are given in No. 3, vol. xxii., of the Astrophysical Journal.

$\mathrm{R}$ Canis Majoris, Z Herculis, and U Sagittæ are shown with certainty to be spectroscopic binaries, their determined velocities corresponding, in sense, to what would be expected from the phase in the light variation at the time of observation.

Variability of the Astirold (444) Gyptis.-The variability of the apparent brightness of the minor planet (444) Gyptis is suggested by the results obtained from a series of observations made at Heidelberg and published by Dr. W. Valentiner in No. 4050 of the Astronomische Nachrichten.

In the same journal it is suggested, by Dr. Palisa, that the magnitude of minor planet $1905 \mathrm{RB}$ is also variable.

\section{CONFERENCE OF DELEGATES OF LOCAL SCIENTIFIC SOCIETIES.}

$A \mathrm{~S}$ it was not deemed expedient to call a meeting of the delegates of the corresponding societies of the British Association during the session in South Africa, it was arranged that a special conference should be convened subsequentiy in Iondon. This meeting was held at the rooms of the Linnean Society on Monday and Tuesday (October 30 and $3 \mathrm{I}$ ), and was largely attended by representatives of various scientific societies in England, Scotland, and Ireland.

Dr. A. Smith Woodward, who presided at the conference, delivered an inaugural address rich in sympathy with the efforts of the provincial societies to further the progress of science, yet not without a word of gentle reproof to such societies as give undue prominence to the picnic element, which rather tends to the estrangement of the working naturalist. Probably the best work of the smaller societies was, in the chairman's opinion, that of instruction in the current progress of science. He sug sested that it would be salutary to dwell on the unsolved problems of science, and pointed out the need of books which should treat of our ignorance rather than our knowledge, and so indicate the direction in which investigation is still urgently needed. Dr. Woodward condemned as extremely unfair the growing practice of certain societies to solicit men of scientific renown to deliver popular lectures without fee. Warm approval was expressed of the recent action of the British Association in secking to cxtend its usefulness by including within its union the smaller non-publishing societies and field clubs, which will form henceforth a new class of associated societies distinct from the group of affiliated societies which publish original investigations in science.

Dr. W. Martin, of the Temple, introduced a discussion on the law of treasure trove, with the view of inducins the various local societies to assist in the preservation of antiquities found within their sphere of influence. While generally defending the law he advocated some revision especially in the mode of its administration. He suggested that notices should be widely circulated, say at the postoffices throughout the country, explaining to the public that the finder of valuable relies would receive reasonable remuneration. In a similar way, relics like stone implements might be secured, where desirable, by the State.

Mr. Morris Colles, the director of the Authors' Syndicate, and Mr. Harold Hardy explained the present law of copyright as it affects the published proceedings of

No. I 880 , voL. 737 scientific societies. The general sentiment of the meeting seemed, however, to be in favour, not of hindering in any way the re-publication of papers, but rather of encouraging the dissemination of knowledge by favouring publication, naturally with due acknowledgment of the original source of information.

Prof. G. S. Boulger read an interesting paper on the preservation of our native plants, which led to a valuable discussion. There seems no doubt that some of the rarer indigenous plants are in serious danger of extermination, not wholly through thoughtlessness on the part of the public, but partly through the cupidity of botanists-an cvil which has increased since the extension of naturestudy. It was proposed that legislation should ultimately be sought for the protection of certain plants, but that meanwhile a circular should be issued bringing the subject before teachers, members of field clubs, and others interested in our flora and likely to assist in its conservation.

In addition to attending the two meetings, the delegates visited the Museum of the Royal College of Surgeons under Prof. Stewart, and, on the evening of October 30 dined at the Royal Societies Club, where they were received as guests.

\section{ZOOLOGY AT THE BRITISH ASSOCIATION.}

THE work of Section D was formally opened on Wednesday, August 16, with the president's address on "The Distribution of African Fresh-water Fishes," which has already been printed in Nature (August 24, p. 413). This was followed by a paper by $\mathrm{Mr}$. L. Doncaster entitled "Recent Work on Gametogenesis and its bearing on Theories of Heredity," which took the form of a résumé of the most important recent work on the relation between the phenomena of nuclear division and those of heredity. It was shown that whilst ample confirmation had been obtained of Weismann's hypothesis that the chromosomes are the bearers of inherited characters, yet the most recent work on the maturation of the germ cells had demonstrated the fact that they contained a mechanism which seemed precisely adapted to bring about that segregation of characters which forms the most fundamental part of the Mendelian theory; it was difficult, therefore, to believe that the two things were unconnected. The remainder of the paper was devoted to the consideration of certain obvious difficulties standing in the way of a complete correlation.

The programme for Thursday, August 17, was opened by Dr. J. D. F. Gilchrist with a paper on cases of extensive mortality among marine animals on the South African coast, with suggestions as to their cause or causes. After narrating specific cases of enormous quantities of fish either dead, or alive but " in a stiffened condition," being thrown up on various points of the coast, the author suggested that these occurrences might be due to a peculiar feature of the Cape seas, viz, the great difference in temperature, salinity, and contents of the warm Agulhas Stream of the Antarctic drift current, and expressed the hope that his notes might be of some use in directing attention to this problem and securing additional evidence in connection therewith. The paper was followed by a demonstration of the more interesting forms in a collection of deep-sea animals shown in the museum of the South African College, special attention being devoted to certain questions, such as methods of reproduction of deep-sea fish, the significance of luminous organs, and parasitism. A short paper by Mr. A. H. Evans on the ostrich and its allies wvas intended to be introductory to a contribution on ostrich-farming by the Hon. Arthur Douglass, one of the pioneers of the industry in the colony. In the latter paper the writer supplied a large amount of interesting information relating to the first commencement of ostrich farming in 1867 and its growth up to the present time, the best climatic and general conditions for the industry, the results of artificial hatching as used in the early days of the industry as compared with present methods of rearing the chicks, the principal diseases of the birds, the present different methods of farming them, the growth of the export of feathers and the range of values, the improvement of the breeds by selection to obtain better feathers, 
the prospects of future development of the industry in South Africa, and of its being successfully developed in other countries. The reports of the committees on grants, which were also taken on this day, did not offer any special points of general interest.

The greater part of the sitting on August 18 was devoted to a paper on the origin of mammals, by Prof. Broom, in which the author had occasion to make extended reference to his work on the Triassic reptiles of South Africa in support of his views of a reptilian origin for the mammalian group. The author gave reasons for believing that in early Permian times a cotylosaurian reptile, owing to its frequenting marshy ground, took to walking with its body well supported off the ground. This habit gave rise to the forward direction of the ilium, and to the pubis and ischium being turned backwards, as also to the great development of the precoracoid. No member of this first stage in the mammalian line was at present known but Pareiasaurus was apparently a considerably modified offshoot from it.

The next stage in the development arose by the marsh animals finding that the new modification of the limbs was specially suitable for progression on land. The new type of land animal was better equipped than the normal reptile, and took to predatory habits and became an active carnivorous animal. These early carnivorous types form the order of Therocephalians, of which about twenty genera are known. Between the Upper Permian and the Upper Triassic times the Therocephalians gave rise to the much improved Theriodonts or Cynodonts. These Theriodonts are almost mammals in every detail of structure, the only essential difference being that the lower jaw has still a small articular element, which hinges on a small quadrate bone. The change from the Theriodont to the mammal was probably brought about by a slight change of habit necessitating some antero-posterior movement of the jaw, the small quadrate bone becoming first a plate of bone and then a plate of cartilage-the inter-articular cartilage, the dentary taking the place of the articular. Neither the auditory ossicles nor the tympanic have ever had anything to do with the articulation. The mammalian malleus was held to be the reptilian extra-stapedial and the mammalian incus the supra-stapedial. The connection between Meckel's cartilage and the malleus, which is hyomandibular, was held to be similar to that between the extrastapedial and the mandibular cartilage in the crocodile. The mammalian tympanic was considered to be the homologue of the distinct tympanic bone of Anomodonts and Theriodonts. The paper gave rise to considerable discussion, in which Prof. W. B. Scott of Princeton, the president, and others took part, and was followed by a communication from Dr. W. F. Purcell on some early stages in the development of Peripatus, in which the writer maintained that an examination of the segmentation stages of the ovum of Peripatus balfouri preserved in formalin shows that the endodermal cells are oval or spherical bodies with well defined convex or flattened contours, but without any anastomosing branches connecting the cells with one another or with the ectoderm. The embryo in the segmentation stages is therefore not a syncytium, as maintained by $\mathrm{Mr}$. A. Sedgwick. The remainder of the session was devoted to an important paper on the habits and peculiarities of South African ticks, by Mr. C. P. Lounsbury, which the sectional committee resolved to print in extenso in the Proceedings of the association, whilst certain details in the structure of the buccal apparatus of a tick (Haemaphysalis punctata) were elucidated in a concluding joint paper by Drs. Nuttall, Smedley, and Cooper.

The first day of the proceedings at Johannesburg (Tuesday, August 29) was opened by Prof. Herdman, F.R.S., who gave an account, illustrated with lantern views, of his well known investigations on the pearloyster beds of Ceylon. This was followed by an interesting communication on Cephalodiscus by Dr. S. F Harmer, F.R.S., in which the author gave a preliminary account of the new species discovered in African seas by Dr. Gilchrist. The session was concluded with a demonstration of ankylostoma preparations by Mr. A. E. Shipley, F.R.S.

The programme for Wednesday, August 30, was opened No. I 880 , rot. 73 by Prof. E. B. Poulton, F.R.S., who gave a lecture, illustrated with lantern slides, on mimicry in South African insects. This was followed by a paper by Mr. W. L. Sclater, director of the South African Museum, on the migration of birds in the southern hemisphere. For the purposes of the paper the author took the list of birds contained in the recently published volumes of the "Fauna of South Africa," written by the late Dr. Stark and himself, together with those of the fourth volume, shortly to be issued. The number of species described in the four volumes was 8I4, which the author divided into five categories, as follows :--residents, 631 ; northern migrants, 76; African migrants, 21 ; partial migrants, 50 ; and island breeders, 36. Mr. Sclater stated that he considered it would be most unwise to evolve any theories on migration in South Africa at present, owing to the dearth of observations hitherto recorded. He was, however, in hopes of making some advance by the distribution of schedules among the lighthouse keepers along the coast, teachers in the schools all over the country, and any others who would undertake to make the observations, for the purpose of recording, day by day and month by month, the appearance of different species of birds.

Mr. C. B. Simpson, the Transvaal Government entomologist, then read a paper on locust destruction in the Transvaal during the season $1904-5$, in the course of which the writer gave an outline of the history of the locust pest in other countries, and then proceeded to describe the locust invasions in South Africa, due to two species, Acridium purpuriferum (the purple locust) and Pachytelus sulcicollis (the brown locust). Although both species were shown to have many natural enemies, yet every natural method of decimation was found to be insufficient. Therefore, in order to save the farmers' crops, recourse had to be had to artificial means. Amongst the methods adopted were beating by hand, tramping with stock, crushing with rollers, burning grass, driving into trenches, the use of locust screens, and spraying. The screens were described in detail with the help of the lantern, the author stating that twenty miles of them were distributed throughout the Transvaal for the use of farmers. Spraying was, however, the most efficient means for the destruction of locusts. The spray used was arsenate of soda, and it was given to the farmers free, while the screens and spray-pumps were lent without charge. The results of the campaign in the previous year had been most gratifying. It was of course stated that the Transvaal, still less South Africa, could not expect to eradicate the pest completely on account of the vast area of unoccupied country; but the author's department did hope to place in the hands of the farmers a means whereby by combined action they could kill the insects and protect their crops. If they could do this they would consider that success had been achieved. With the purple locust the author believed they had proved that the farmers could do this, but with the brown locust they had not yet had sufficient experience to be able to tell whether they could prevent injury or not. The concluding paper of the session, by Dr. H. Lyster Jameson, was entitled "On Some South African Land Planarians," and dealt with certain points in their anatomy.

The concluding meeting of the section was held on Friday, September r, on which day Prof. W. B. Scott, in an opening paper on convergent evolution as illustrated by the Litopterna, maintained that while convergent evolution was admitted by most naturalists to be a frequent and important phenomenon, there was a great difference of opinion as to how nearly identical the results of such a mode of development might be. So far as the Litopterna were concerned, there were striking resemblances to certain Perissodactyls in teeth, skull, and skeleton, but the differences were many and fundamental. It did not appear at all likely that so complex a structure as a mammalian skeleton was ever produced in identical terms by two independent series.

In the course of the succeeding paper, on a neurosyncytial theory of development, Dr. W. H. Gaskell, F.R.S., referred to his theory of the origin of vertebrates, and pointed out that it was based upon the paramount importance of the central nervous system as the chief factor in the upward progress of the animal kingdom. Every line of investigation pointed to the conclusion that the 
vertebrate arose from that group of invertebrates which possessed a central nervous system most nearly similar to that of a low vertebrate such as Ammocœetes, an invertebrate, therefore, belonging to the group of arthropods. This argument had been worked out by the author in a series of papers published in the Journal of Anatomy and Physiology, and receives especial support from the palæontological record. For the dominant race now, the biped mammal man, arose undoubtedly from the highest race evolved up to that time-the quadrupedal mammals; these in their turn originated from the dominant reptiles; these again from the amphibians, which were the most highly organised group of their day. The amphibians themselves came from the dominant race living in the sea at the time-the fishes; so, too, according to the author's theory, the fishes arose directly out of the race previously dominant, i.e. the arthropod group. This theory necessitates the formation of a new alimentary canal at the transition from the arthropod to the vertebrate-a requirement which is no more unlikely than the formation of a new respiratory apparatus at the transition of a fish into an amphibian. The reason why others have found this formation of a new alimentary canal so difficult of acceptance is because embryology-and embryology alone-in its recent teaching makes the alimentary canal, and not the central nervous system, the important organ around which the animal is built up. The author, basing himself especially on Braem's papers in the Biologisches Centralblatt, pointed out that in reality the germinal layer theory was a physiological and not a morphological conception, that the one criterion of hypoblast was not its mode of formation but its ultimate fate; whether or no, the definite alimentary canal was formed from it. Morphological laws of development must exist, but to quote Samassa, "one thing can be said with certainty at the present time, the germinal layer theory is not one of them." The author suggested a re-consideration of the whole matter, and, starting with the adult, pointed out that the tissues of the body fall naturally into two great groups, those which are connected with the central nervous system, the master tissues of the body, and those which live a free existence without any such connection. The body might be looked upon as composed of a neuroepithelial syncytium, in the meshes of which free cells live.

Prof. Cleland, F.R.S., in conclusion, read a communication on the growing-point of the Vertebrata, in the course of which he pointed out that while the medullary folds appear in close connection with the blastopore, and the parts concerned with the cranium and its contents are the first to appear, both mesoblastic somites and spinal nerves appear in succession, each metamere behind that which is immediately proserial to it. It follows, therefore, that it is from the short space between the medullary folds and blastopore that new metameres of the neuromuscular system are formed, and there is no reason to doubt, the author held, that the visceral system is extended in the same manner. The nucleated corpuscles of this region furnished, therefore, in his opinion, the parents of the corpuscles of which the successive metameres of the trunk are composed, and they do so by giving off successive series of corpuscles which belong each to a particular metamere.

\section{EDUCATIONAL SCIENCE AT THE BRITISH ASSOCIATION.}

THE most noteworthy feature in the educational science section at the South African meeting of the British Association was the address of its president, Sir Richard Jebb, an address which was originally delivered at Cape Town, and repeated with a little variation at Johannesburg. The address, which was printed in full in Nature of September 28 (p. 545), dealt with the idea of a university and the distinction which marks off the teaching of a university from that of a higher technical school or similar institution.

The subject of the address was the more apposite in that the most pressing educational question in South Africa at the present time is the creation of a teaching university. The present Cape University is an examining NO. I 880 , vOL. 73 ] body only, and it has been suggested that the time has come for it to grow into a teaching university by the combination of the colleges at present preparing for its examinations, much as the University of London was so recently re-created. The difficulties, however, both of funds and of conflicting interests have not yet been overcome.

At Johannesburg, also, the successful start of the recently established technical institute has led to a plan for its growth into a university, with engineering, agriculture, law and education as its main faculties, and it seems not unlikely that liberal financial support would be forthcoming should it be decided on fuller consideration to adopt such a scheme.

At the sectional meetings a large proportion of the papers was contributed by teachers resident in South Africa, so that opportunities were afforded to the visitors of learning what were the more pressing educational problems, and to the local members of discussing these problems on a wider platform. At Cape Town the Rev. W. E. C. Clarke gave a general review of the development of education in the colony, laying particular stress on the perennial difficulty of providing any efficient scheme for the instruction of the widely scattered country population. Mr. Clarke's paper excited considerable interest, and led to renewed discussion, especially the latter portion, which dealt with the status of the teacher in Cape Colony. He spoke of the power of the Cape Teachers' Union, and deplored the tendency of their conferences to be rather exclusively occupied with questions of salary and allowances instead of leading public opinion on matters of educational policy.

Mr. W. W. Way, principal of the Graaf Reinet College, also contributed a brilliantly written and hard-hitting paper on the disabilities of the South African schoolboy. He pointed out how the semi-tropical climate, the wealth of sun and air, the freedom and isolation of the life of the South African boy, while they produce an alert and selfreliant race, do not work well in the interests of education. The youth are essentially undisciplined and unintellectual, while the early physical development brings its own dangers. Mr. Way touched upon the further difficulties, both as to mind and morals, which arise out of the proximity of the native, the co-existence of two languages, the inferior type of teacher that characterised the past, and the narrowing influence of many of the religious bodies in the country. Nothing but an ampler endowment and a general rise in the status of the teacher can induce in the future South African a proper respect for his intellectual development.

The general history and administration of education in the other colonies were thoroughly dealt with at the Johannesburg meeting in a series of papers contributed by Mr. Warre Cornish, Mr. Gunn, and Mr. Duthie. They all showed certain common problems-the scarcity of suitable teachers and the necessity of improving their status and training, the expense of providing adequate school buildings, and the difficulties induced by the isolation of the farms. This latter question of education upon the Veld was also dealt with in a breezy paper by Mr. J. H. Corbett, a vivid and sympathetic presentation of the case, in which the author evidently trusted more to the selfdevotion of the individual teacher than to any possibilities of organisation.

The second meeting at Cape Town opened with a paper by Mr. W. M. Heller on the methods of teaching science, with an introduction by Prof. H. E. Armstrong. At its close Mr. Oscar Browning expressed his dissent from the current view of the "heuristic" method-as an instrument of education it was valueless, and all good teachers of history and literature had worked by this method long before Prof. Armstrong resuscitated its unhappy name. Mr. A. D. Hall claimed that the value of the "heuristic" method lay in the inspiring ideal it set up; unrealisable as it might be, the natural tendency of the teacher was to drift along the other easier way of giving instruction ex cathedra instead of by the path of discovery and experiment. Mr. G. Fletcher, however, rather hit off the feeling of the mecting when he suggested that a close time should be declared for discussions of the "heuristic " method, which had in past years occupied far too much of the 